\title{
How can states benefit from the equity premium puzzle? Debt as revenue source for Swiss cantons
}

\author{
Ramon Christen $^{1^{*}}$ (D) and Nils C. Soguel ${ }^{2}$
}

\begin{abstract}
This paper addresses the question of the optimal debt level of a state (canton) that issues new bonds and subsequently invests the borrowed capital. For that purpose, we first estimate the effect of the debt level on the interest rate and then we contrast the predicted interest rate with potential revenue from the capital markets. The estimation is based on panel data from the 26 Swiss cantons between 1980 and 2015. The median performance of Swiss pension funds serves as a reference value for the revenue achieved in the capital market. The results show an exponential relationship between the debt and its interest rate; raising indebtedness by 1000 Swiss francs per capita makes the spread between the risk-free rate and the interest rate on the debt increase by $5 \%$. Given this small effect, the inherent optimal debt level equals more than twice the initial levels and the reinvested uncommitted funds provide a return potential of nearly $5 \%$ of the total cantonal receipts, on average.
\end{abstract}

Keywords: Public debt management, Government bonds, Sustainability, Credit market, Regional government, Equity premium puzzle

\subsubsection{Classification $\mathrm{H} 63, \mathrm{H} 68$}

\section{Background}

This paper argues that governments can benefit from higher indebtedness. When the price of the borrowed capital falls below the return rate in the capital markets, the government can issue bonds and invest the raised capital on the capital market. These leveraged investments yield a net profit to the government, which is reinforced when taking the equity premium puzzle into account. The equity premium is the discount on the interest rates of public bonds in comparison to other asset classes that remain after deducting the risk premium. Nevertheless, such a practice has its limits, because an ascending debt level amplifies the default risk, leading lenders to ask for higher yields. If the government stretches it out, the costs of borrowing exceed the return rate and the leveraged investments become unprofitable.

The combination of a fixed return rate and a dynamic interest rate motivates the main research question treated

\footnotetext{
* Correspondence: ramon.christen@ch.pwc.com

${ }^{1}$ PricewaterhouseCoopers AG, Bahnhofplatz 10, 3001 Bern, Switzerland Full list of author information is available at the end of the article
}

here. What is the optimal debt level of a government that utilizes available but uncommitted financial assets for leveraged investments in the capital markets? To establish this, one needs to first identify what determines the interest rate of the public debt. The debt level itself is the most salient of these determinants, and taken together, they make it possible to trace an interest rate curve along the debt axis. The interest rate curve then allows one to estimate an interest rate for each debt level (ceteris paribus) and also suffices for estimating the optimal debt level. In the last step, we report profit estimates a government can expect if it follows such a debt optimization strategy.

In our model, when the government increases its debt, the interest rate on the debt grows exponentially. Based on our estimates, raising indebtedness by 1000 Swiss francs (CHF) per capita makes the spread between the risk-free rate and the interest rate on the debt (the interest spread henceforth) increase by $5 \% .{ }^{1}$ Since the model is non-linear, the absolute values of the interest rate depend on all the other determinants of the debt's interest rate. On average from 1997 to 2015, the optimal debt level of the Swiss cantons amounted to 17,736 Swiss francs per capita, more than double the mean actual debt of 7027 
Swiss francs per capita. If one always set the debt at its optimal level, this would add $4.78 \%$ to total cantonal receipts. With more conservative strategies, this would, on average, drop to below $1 \%$.

It is striking that the optimal debt level exceeds the actual debt level by this much, but it results from the temporary high return rates in the capital markets, the relatively inelastic interest rate with respect to debt, and from our assumption of a risk-indifferent government. Yet, doubling the current debt does not yield aberrant values since cantons are in general moderately indebted.

Accounting for profitable assets on state balance sheets adds to the existing literature on the sustainability of public debt. The classic public finance literature considers high indebtedness problematic because it carries a risk of falling into the debt trap. Blanchard et al. (1991) consider a fiscal policy to be sustainable over the long run if the debt-to-GDP ratio remained stable. Their model included only gross debt, GDP growth, the interest rate, receipts, and expenditures, and was based on holding the tax rate constant and using an intertemporal budget constraint.

In its simplicity, this model neglected two important aspects that affect debt sustainability. First, focusing on gross debt disregards assets. Referring to the same model, Blankart (2017) justifies the preference for the gross over of the net debt by arguing that a government's assets are usually assumed to be inalienable: subtracting them would present the fiscal situation as better than it actually is. Moreover, asset valuation can vary significantly, which makes it hard to compare. However, both arguments are untenable for assets composed of liquid financial investments (Giammarioli, Nickel, Rother, and Vidal, 2006). Second, excluding assets ignores the revenue they can potentially generate.

The literature which focuses specifically on the management of government assets and liabilities does acknowledge the contribution to revenue which spare (uncommitted) funds make. However, these articles tend to treat the returns from uncommitted funds as a welcome byproduct rather than as main objective of asset management. Instead, the asset and liability management literature subordinates the debt level in favor of guaranteeing constant solvency (Das, Lu, Papaioannou, and Petrova, 2013).

Bohn (2002) goes one step further in his consideration of strategies a government that holds uncommitted funds could take. One of his proposals argues that "a positive [equity] premium provides an arbitrage opportunity for the government $[. .$.$] to earn seigniorage-like profits by issuing$ debt and investing the proceeds." While this strategy implies the existence of an optimal debt level, Bohn leaves the question unanswered of how to determine this optimum.

To our knowledge, there is no other literature which discusses such asset and liability practices. As a result, our paper links two strands of argument together. The first strand relies on earlier studies estimating the influence of debt on the borrowing cost of a state. The second draws on the literature about the equity premium, meaning the spread between the interest rate on public debt and the return rate from other assets on the capital market (the return spread henceforth).

The list of publications estimating the interest rate curve in relation to the debt is long and covers not only different layers of government but also several geographic regions. The first studies dealing with the dependence of public debt on the interest rate focused on the USA. Barth, Iden, and Russek (1984) reviewed some of the early studies that examined this effect at the federal level and replicated them successfully. Later, researchers improved on the models and analyzed other levels of government (Bayoumi, Goldstein, and Woglom, 1995; Capeci, 1994; Poterba and Rueben, 1997). Later on, the geographical scope widened not just to Canada (Booth, Georgopoulos, and Hejazi, 2007; Schuknecht, von Hagen, and Wolswijk, 2009) but have included comparisons of 20 industrialized and developing countries (De Mello, 2001), and emerging market countries (Akitoby and Stratmann, 2008). Later, the work of Manganelli and Wolswijk (2009) and Attinasi, Checherita, and Nickel (2011) offered an overview of the European area. Küttel and Kugler (2002) and Feld, Kalb, Moessinger, and Osterloh (2017) focused on Swiss cantons. In the many national and international studies addressing this question, the debt level has always served as an explanatory variable and, if it is significant, it usually affects the interest rate positively.

Most studies have analyzed panel data and began with simple fixed effects estimators. Because of endogeneity and autocorrelation, more sophisticated methods integrating instrumental variables often followed, not least because endogeneity creates a major problem in the econometric estimations. More precisely, whereas Capeci (1994) assumed a reverse causality between the debt level and the interest rate, Bayoumi et al. (1995) looked at factors that simultaneously influence both. The functional form of the interest rate curve has also been intensively discussed, with Baldacci and Kumar (2010) finding some evidence for non-linearities in the relationship. Our research incorporates both concerns. The endogeneity problem is tackled using the system general methods of moments (GMM) estimator (Blundell and Bond, 1998). As regards the functional form of the interest rate curve, we follow Akitoby and Stratmann (2008), who theoretically deduced an exponential link between the interest spread and its determinants.

The second strand of literature related to leveraged investment investigates the return spread, whereas the risk-free rate is usually put on a level with long-term government bond yields. The classic financial market theory that accounts for the risk premium and the 
default premium does not entirely explain the return spread. Apparently, the solution hides within the surprisingly cheap borrowing costs of the government. Put differently, " $\mathrm{t}]$ he equity premium puzzle may not be why was the average equity return so high but rather why was the average risk-free rate so low" (Mehra and Prescott, 1985, p. 158). So either investors are particularly risk-averse and therefore accept a special discount for risk-free bonds, or transaction costs, in the form of credit ratings, disappear in the case of government bonds, as they are considered risk-free anyway. Based on these two explanations, Bohn (1999) examined the conditions under which exploiting the equity premium puzzle is beneficial from a taxpayers' point of view. However, his understanding of exploiting low-interest rates confined itself to the analysis of generational risk distribution. $\mathrm{He}$ did not consider profitable investments. In a later empirical investigation, he found that the equity premium disappears at a certain level of debt. The government should therefore keep its debt level below a certain threshold in order to benefit from generous interest rates (Bohn, 2011). For our purposes, this literature strand justifies the focus on the interest rates of government bonds, as they constitute the origin of the inexplicably large return spread.

When it comes to testing the theory, the Swiss cantonal setting, a second layer of government comparable to USA states, is valuable because it enables an empirical test of the theory. In terms of fiscal, economic, demographic, and institutional factors to investigate, the cantons vary considerably. Yet, the cantons are uniform in terms of the definition and measurement of fiscal indicators (Krishnakumar, Martin, and Soguel, 2010). Based on panel data from all 26 cantons over the period from 1980 to 2015 , we estimate the interest rate as a function of the debt level. After that, we relate the estimated interest rate with the median performance of the Swiss pension funds which serves as a reference value for the revenue achieved in the capital market (see below).

The rest of the paper is structured as follows. Section 2 highlights the methods. More precisely, it takes up the theory of the classic debt trap and adds assets together with their revenues to it. The following two subsections are dedicated to the identification strategy and to the declaration of the empirical field; it also contains the data. The subsequent section three presents our estimations of the interest rate curve and the attainable profits. Section 4 concludes the paper.

\section{Methods}

\subsection{Considering assets to overcome the classic debt trap}

Blanchard et al. (1991) formalized the sustainability of public debt relatively simply. They defined the current debt as the sum of the previous gross public debt $B$, of the debt service $i B$, where $i$ denotes the interest rate, and of the government expenditures before interest payments $G$ minus total receipts $R$; subscripts indicate the year:

$$
B_{t}=G_{t}-R_{t}+B_{t-1}+i B_{t-1}
$$

As long as the primary balance $G-R$ finances the debt service, the debt is considered sustainable; otherwise, the government falls into the debt trap. In other words, sustainability is defined as $B_{t}-B_{t-1} \leq 0$. Using this definition and dividing (1) by the gross domestic product (GDP) $Y$, the sustainability condition becomes less restrictive, as economic growth can compensate for an increase of the absolute debt:

$$
\begin{aligned}
\frac{B_{t}}{Y_{t}} & \leq \frac{G_{t}}{Y_{t}}-\frac{R_{t}}{Y_{t}} \\
& +\frac{(1+i) B_{t-1}}{(1+g) Y_{t-1}} \quad \text { where } \quad g_{t} \equiv \frac{Y_{t}}{Y_{t-1}}-1
\end{aligned}
$$

where $g$ represents the economic growth. Approximating $\frac{(1+i)}{(1+g)} \approx 1+i-g$ if $g$ and $i$ are close to zero and rearranging (2) yields:

$$
\frac{R_{t}}{Y_{t}}-\frac{G_{t}^{*}}{Y_{t}} \geq\left(i_{t}-g_{t}\right) \frac{B_{t-1}}{Y_{t-1}}
$$

Inequation (3) shows that the primary surplus must be at least as high as the weighted difference between the interest rate and economic growth. Furthermore, if the economy grows strongly enough compared to the interest rate, a primary deficit does not necessarily lead to an increased debt rate.

In line with the classic model, debt has thus far implicitly been considered in gross terms. For the sake of simplicity, set the equity equal to zero such that the liability side only consists of gross debt. Taking now the asset side of the balance sheet into account, denote $K$ as the productive capital, meaning the amount of public assets bound to functions of the government such as infrastructure, schools, or hospitals. This is the inalienable part mentioned above and, by assumption, it does not generate any financial return for the government. Denote $I$ as the amount of public assets that is unbound (i.e., uncommitted). ${ }^{2}$ Assume that $I$ generates revenue with a return rate $r$. Accordingly, the total receipts $(R)$ now consist of taxes, transfers, and other receipts, characterized by $T$ on the one hand. On the other hand, the return on the unbound assets $I$ (i.e., $B-K$ ) also contributes to total receipts, such that $R_{t}=T_{t}+r_{t}\left(B_{t-1}-K_{t-1}\right)$. Substituting $R$ in (3) and rearranging yields:

$$
\frac{G_{t}}{Y_{t}}-\frac{T_{t}}{Y_{t}} \leq\left(r_{t}-i_{t}-g_{t}\left(r_{t}-1\right)\right) \frac{B_{t-1}}{Y_{t-1}}-r_{t}\left(1-g_{t}\right) \frac{K_{t-1}}{Y_{t-1}}
$$

If the inequality holds, the debt is sustainable, and the smaller (larger) the left side (right side) of the inequality, 
the lower is the risk of falling into the debt trap. Accordingly, under the condition that $g(r-1)<r-i$ holds, it is beneficial to raise the debt $(B)$. As regards the interpretation of this condition, first note that in a growing economy $(g>0)$ with a return rate which equals or exceeds the interest rate $(r \geq i)$, the condition is met and the government benefits from raising the debt. Second, in a shrinking economy $(g<0)$, the interest rate needs to be negative $(i<0)$ as soon as economic growth drops below the level of the return rate $(g<r)$. Third, part of the difference between the interest rate and the return rate accrues from the equity premium puzzle. Note that raising the debt can already be beneficial in inequation (3) if the economic growth exceeds the interest rate (Blankart, 2017). However, with the division of the debt, obtaining receipts by raising the debt is also possible if the interest rate exceeds economic growth.

This advanced debt trap indicates that a government can use the equity premium puzzle without risking an unsustainable debt under the assumption that the interest rate is independent of the debt level. In the following, we examine a government's profit potential from raising the debt in a single year when the interest rate increases with the debt level, but without considering the relative terms. Assume that at stage 0, the government has outstanding debt of $B_{0}$, which is entirely bound up in productive capital $K$ and does not yield any revenue. The government pays interest in the amount of $B_{0} i_{0}$. Then, at stage 1 , the government decides to benefit from the equity premium puzzle and issues a new bond. The total outstanding debt is now $B_{1}(K+I$ above). Due to the increase in the debt, the capital market charges a higher interest rate $i_{1}$, such that the total interest paid is $B_{1} i_{1}{ }^{3}$ At the same time, the government invests the unbound assets $I=B_{1}-B_{0}$ with a return rate $r$, obtaining a return of $\left(B_{1}-B_{0}\right) r$. The profit (II) results from the difference between the additional receipts and the additional expenditures:

$$
\begin{aligned}
\Pi & =\left(B_{1}-B_{0}\right) r-\left(B_{1} i_{1}-B_{0} i_{0}\right) \\
& =B_{1}\left(r-i_{1}\right)-B_{0}\left(r-i_{0}\right)
\end{aligned}
$$

Above, we already imposed the assumption that the interest rate on the debt is endogenous, or more precisely, that the interest rate curve as a function of the debt is increasing and convex (Kumar and Baldacci, 2010). ${ }^{4}$ To approximate the adjustment of the interest rate due to higher debt, we follow Akitoby and Stratmann (2008). They split the interest rate into a risk-free rate $f$ and a risk premium. We define the latter as interest spread $s \equiv i_{1}-f$. A risk-indifferent lender demands an interest spread such that it compensates for a potential default that is defined as occurring with probability $p$, formally: $(1+f)=(1-p)(1+s+f)$. Rearranging yields $s=\frac{p}{1-p}(1+f)$ and we parametrize the default probability as $p \equiv \frac{\exp \left(\gamma B_{1}+\boldsymbol{\beta}^{\prime} \boldsymbol{x}\right)}{1+\exp \left(\gamma B_{1}+\boldsymbol{\beta}^{\prime} \boldsymbol{x}\right)}$. Together with the debt level $B_{1}$, the parameter vector $\boldsymbol{x}$ determines the default probability weighted by the coefficients $\gamma$ and $\beta$. Substituting $p$ and rearranging results in $s=\exp \left(\gamma B_{1}+\boldsymbol{\beta}^{\prime} \boldsymbol{x}\right)(1+f)$ or in logarithmic terms $\ln (s)=\gamma B_{1}+\boldsymbol{\beta} \boldsymbol{x}+\ln (1+f)$. The last summand is constant and affiliates to the constant in $\boldsymbol{x}$. Hence, the interest spread is determined by the following exponential function:

$$
\ln (s)=\ln \left(i_{1}-f\right)=\gamma B_{1}+\boldsymbol{\beta}^{\prime} \boldsymbol{x}
$$

The coefficients of (6) are estimated in the empirical part. Note that the convexity assumption above requires $\gamma$ to be positive. Having defined the functional form of the interest rate, this allows us to derive an optimal debt level $B_{1}^{*}$ which maximizes profit. The optimal debt level $B_{1}^{*}$ satisfies the following condition:

$$
\begin{aligned}
\frac{\partial \Pi}{\partial B_{1}} & =\mathrm{r}-i_{1}-B_{1}^{*} \frac{\partial i_{1}}{\partial B_{1}^{*}} \\
& =r-\left(\exp \left(\gamma B_{1}^{*}+\boldsymbol{\beta}^{\prime} \boldsymbol{x}\right)+f\right)-B_{1}^{*} \gamma \exp \left(\gamma B_{1}^{*}+\boldsymbol{\beta}^{\prime} \boldsymbol{x}\right) \\
& =0
\end{aligned}
$$

Solving (7) with respect to $B_{1}^{*}$ is impossible because of the exponential specification of the interest spread (6). Yet, even if no exact analytical solution for $B_{1}^{*}$ in condition (7) is feasible, there is nonetheless a numerical one. The function to solve for $B_{1}^{*}$ is

$$
\gamma B_{1}^{*}+\boldsymbol{\beta}^{\prime} \boldsymbol{x}+\ln \left(1+\gamma B_{1}^{*}\right)=\ln (r-f)
$$

The following subsection proposes an estimation strategy to evaluate the parameters, which enables one to determine $B_{1}^{*}$. Note that in reality, the government would probably also consider the risk of a loss; this is not considered here. The government, just as the lender, is assumed to be risk-indifferent.

\subsection{Identification strategy}

In order to identify the coefficient of debt, i.e., $\gamma$, we need to eliminate all confounding variation in the dependent variable. In a first step, this means addressing the endogeneity issues. The second step follows in the subsequent section and identifies the covariates necessary for identification.

As already stressed in the literature review, the decision to invest and to issue new debt depends on the cost involved, which induces an endogeneity problem when estimating the effect of the debt level on the interest rate. Another endogeneity problem emerges with the model specification. Due to the high persistence of interest rates, ${ }^{5}$ several authors recommend a dynamic panel data model, where the lagged dependent variable enters as an additional regressor (Attinasi et al. 2011). Based on (6), the estimation equation then becomes: 


$$
\begin{aligned}
\ln \left(s_{c, t+1}\right)= & \beta_{0}+\delta \ln \left(s_{c, t}\right)+\gamma B_{c, t}+\boldsymbol{\beta}^{\prime} \boldsymbol{x}_{c, t}+\alpha_{c} \\
& +\epsilon_{c, t}
\end{aligned}
$$

where the subscripts $c$ and $t$ denote the canton and the time, respectively. Besides the error term $\epsilon_{c}, t$, the estimation Eq. (9) expands the primal function of the interest spread curve (6) by a cantonal fixed effect $\alpha_{c}$. In addition, the interest spread is delayed by one time period because lenders cannot respond to the information in the same year they receive it (Engen and Hubbard, 2004). Accordingly, the lagged dependent variable corresponds to the same year as the covariates. The standard approach to eliminate the individual fixed effect transforms the data into first differences, whereby the equation becomes

$$
\Delta \ln \left(s_{c, t+1}\right)=\Delta \ln \left(s_{c, t}\right) \delta+\Delta B_{c, t} \gamma+\sum_{l} \Delta x_{c, t, l} \beta_{l}+\Delta \epsilon_{c, t}
$$

At this point, the endogeneity issue occurs again, since the differenced lagged dependent variable depends on the differenced error term. ${ }^{6}$ Pleasantly, Arellano and Bond (1991) propose a set of internal instruments that obviate the search for additional variables. They find that the second lag of the dependent variable (i.e., $\ln \left(s_{c, t-1}\right)$ ) satisfies the requirements of an instrument. ${ }^{7}$ In fact, deeper lags (i.e., $\left.\ln \left(s_{c, t-2}\right)\right)$ are suitable too, and they potentially increase the efficiency. The missing values of earlier observations which thereby automatically result can be replaced by zeros in the instrument matrix, which prevents losing observations. Under the assumption that the differenced lagged dependent variable $\left(\Delta \ln \left(s_{c}, t\right)\right.$, i.e., changes in the interest spread) are independent of the cantonal fixed effects $\left(\alpha_{c}\right.$, e.g., a systematic discrimination of a canton due to an unobservable factor), additional instruments can increase the efficiency even further. Exploiting this assumption, Blundell and Bond (1998) suggests adding level equations, where the differenced endogenous variables are suitable as instruments for their respective levels. This estimator came to be known as system GMM. For the reasons outlined above, the system GMM seems to be the most appropriate estimator for our purpose. ${ }^{8}$

\subsection{Empirical field and variables}

The 26 Swiss cantons offer considerable longitudinal data going back to 1980 . To identify and categorize the determinants of a cantonal default, Daldoss and Foraita (2003) developed a framework to rate Swiss polities which included institutional conditions, budget stability, and financial capacity. Further literature has provided specific measurable variables to fill in these categories.

The first category, the institutional conditions, gives an indication of a canton's future debt potential. This can be derived from the underlying rules that are often legally or constitutionally enshrined. These may include debt limitations based on balance sheets, funds, or special financing not on balance sheets, or current accounts. Regulations mandating disclosures are also part of the institutional conditions (Daldoss and Foraita, 2003). Previous studies have found significant negative effects debt brakes exercise on interest rates (Feld et al. 2017). The debt brake index takes on higher values the more comprehensive the fiscal rule is, that is, when the following elements are considered: the connection between budget planning and execution, numerical constraints, and effective sanctions in the form of tax increases. Similarly, more stringent fiscal referenda lead to lower interest rates (Feld and Kirchgässner, 2008; Luechinger and Schaltegger, 2013). The index which approximates the stringency of referenda is based on the number of signatures necessary to launch the referendum relative to the total population (Frey and Stutzer, 2000). Finally, lenders may penalize arbitrary financial information and therefore demand higher risk premiums from cantons operating under older or less-known accounting standards.

The second category, budget stability, is informational and deals with current data (Daldoss and Foraita, 2003). Gross debt is the most pertinent variable here and consists of current, short-term, and long-term liabilities. Interest receivable serves not only a proxy for government solvency, but it also approximates existing unbound assets (denoted $I$ above) that already generate revenues. Likewise, lenders might reduce the interest spread when a canton has more direct control over their revenue sources. We therefore include tax revenue as an additional control variable. Further, overall fiscal balance gives the lenders a clue as to whether the borrower will be able to repay his debt. Repeated deficits suggest problems with debt reimbursement (Booth et al. 2007; Küttel and Kugler, 2002). ${ }^{9}$ Before 2003, lenders also had to keep an eye on the fiscal balance of municipalities, as it was unclear whether cantons were obliged to bail them out in case of insolvency. In 2003, the Swiss Supreme Court denied this obligation. To test the respective effects on the interest rate of the cantons, one variable capturing the municipalities' overall fiscal balance, a dummy variable that takes the value 1 after 2003, and the interaction of these two variables are included in the model (Feld et al. 2017).

Capacity is the operative word of the third category, financial capacity, which connects the two other categories as it provides information about the present and the future. A strong economy indicates a potential for higher tax revenue. Higher tax revenues enlarge the scope for paying back outstanding debt, which pushes down interest rates (De Mello, 2001; Engen and Hubbard, 2004). By contrast, the more the unemployment rate rises, the lower the tax revenue is expected to be. ${ }^{10}$ Hence, the 
latitude for debt servicing is lower. Controlling additionally for, and thus holding constant, the population and its growth, makes it possible to more precisely identify through which channel GDP influences interest rates. Furthermore, a higher proportion of elderly and younger citizens exert upward pressure on expenditures while they contribute relatively weakly to the tax base (Krishnakumar et al. 2010). Lenders might use the population share above 65 and below 18 years as a predictor of increased fiscal stress. The amount of money that a government spends on public services also depends in part on its ideological background. Right-wing and conservative parties tend to be associated with a more restrictive fiscal policy. Lenders can expect a lower probability of default if these parties are in power (Akitoby and Stratmann, 2008). The variable "bourgeois parties in executive" expresses the fraction of right-wing and conservative parties in the cantonal executive council. Finally, politicians might also have an incentive to manipulate fiscal variables at the end of their term. We therefore include a dummy indicating the year before an election.

As concerns the dependent variable "interest spread", we base our arguments on De Mello (2001), who calculates the interest rate on public debt by dividing the debt service by the gross debt. This is an appealing measure for Switzerland because the Federal Finance Administration provides the respective values for all Swiss cantons for all the years examined. To account for the problem that gross debt varies throughout the year but debt servicing only provides a snapshot at the end of the accounting period, we use the mean of the debt level at the beginning and the end of the year.

Operationalizing the interest rate is only half of the measure of the interest spread. The risk-free rate still needs to be determined, and its typical proxy is the yield of a 10-year national government bond. However, proceeding this way leads, in the Swiss case, to the problem that almost half of the cantons repeatedly exhibit negative values in their interest spread, and using logarithms results in all of these observations dropping out of the analysis. As an alternative, we define the smallest annual cantonal interest rate as the risk-free rate. While this approach confines the loss of data to one observation per year, ${ }^{11}$ it also systematically excludes the cantons with the lowest interest rates from the sample (i.e., it truncates the data). Consequently, the resulting coefficients provide an overly conservative picture, as they are likely to be biased towards zero (Greene, 2003). Although a robustness check relativizes the truncation issue, it needs to be kept in mind when interpreting the results.

Using these variables allows us to estimate the coefficients of the interest spread curve (9). However, to calculate the optimal debt level using Eq. (8), the possible return from the capital market is missing. The possible return depends on the risk a canton is allowed or willing to take. On the one hand, cantonal asset and liability rules usually prohibit the cantons from leveraged venturing in the capital markets. On the other hand, they specify which categories to invest liquid assets, and they are comparable to those mentioned in the Swiss Federal Law on Occupational Retirement and its subsidiary ordinance. The two decrees dictate where the Swiss pension funds may invest. If a certain risk corresponds to each investment category and the cantons are allowed to invest in the same categories as the Swiss pension funds, then the actual return of the pension funds and the possible return of the cantons are equal. Thus, the return of the Swiss pension funds is an adequate reference value for the possible return of the cantons. ${ }^{12}$ A yearly survey among the Swiss pension funds reports the median values of their performance since 1997 (see Swisscanto Vorsorge AG, 2017 for the most recent study). Figure 3 in the Appendix illustrates the respective data.

Table 3 gives an overview of the variables and yields some preliminary empirical insights. While the cantonal interest rate averages $3.36 \%$, the mean risk-free rate comes to $1.49 \%$, leading to an interest spread of $1.87 \%$ on average. Taking the debt as the main regressor, its variation is conspicuous. The average gross debt is moderate, at a level of 6000 Swiss francs per capita. Breaking ranks, the two cantons of Basel City and Geneva had an average debt per capita of over 20,000 Swiss francs between 1980 and 2015. Yet, the interest rates of these two cantons do not substantially exceed those of the others.

To show the time-related development of the observed values, Fig. 1 plots the interest spread and the debt per capita of the Swiss cantons in 1980 and 2015. The theory would predict a convex point cloud from the lower left to the upper right corner. Considering the black dots only (i.e., observations from 2015), one can actually observe a tendency, though one cannot discern a trend in the white dots (i.e., 1980). Likewise, the temporal dynamics are equally unclear. Most cantons benefited from a lower interest rate in 2015 compared to 1980; worldwide sagging interest rates may have contributed to this. At the same time, few cantons were able to reduce their debt.

\section{Results and discussion}

\subsection{Estimated interest rate curves}

In order to contrast the more sophisticated System GMM estimator, we first present the results of an OLS regression with cantonal fixed effects, as reported in model 1 in the first column of Table 1. As Nickell (1981) demonstrates, the estimated coefficient of the lagged dependent variable (here amounting to 0.761 ) is downward biased because of the inherent endogeneity; the 


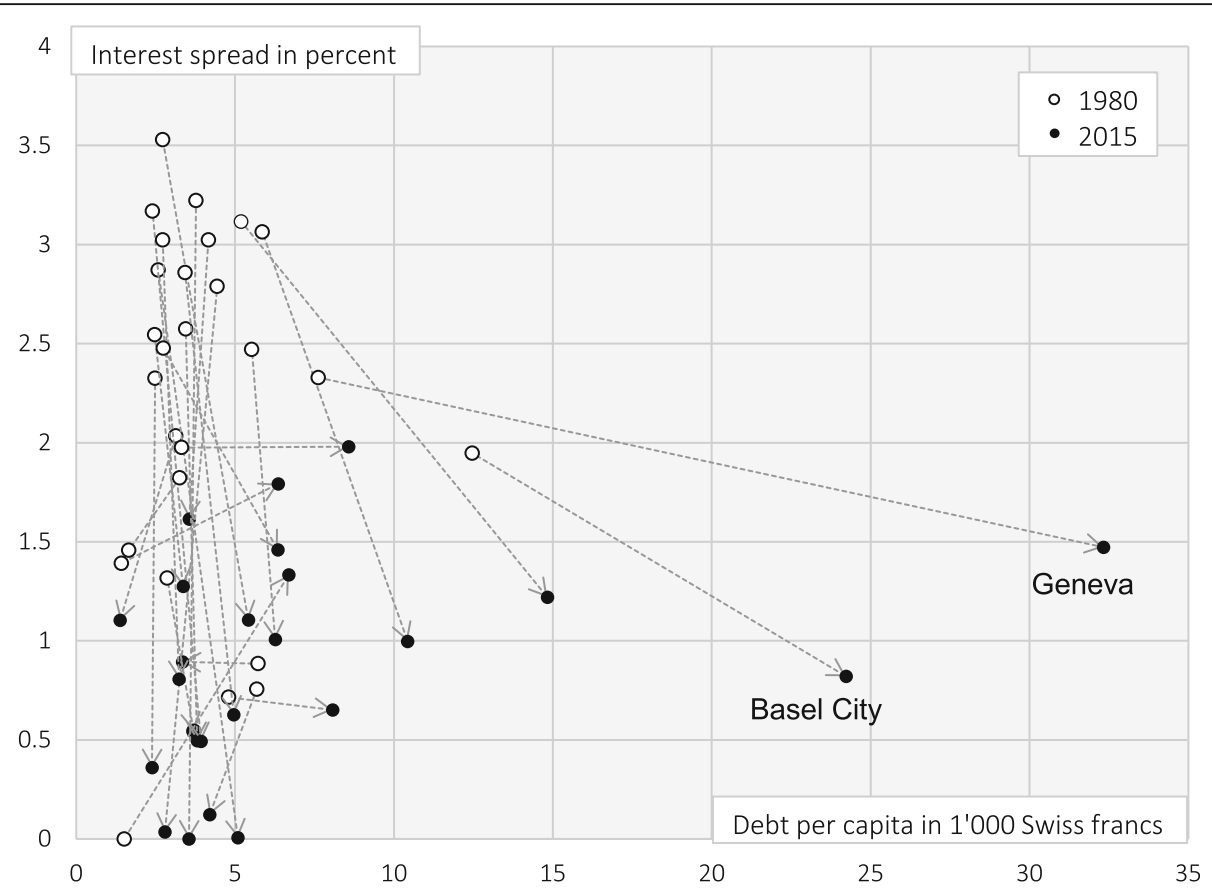

Fig. 1 Interest spread and debt per capita of Swiss cantons 1980 ad 2015

other regressors are inconsistent too. The debt coefficient is very small and not significant, just as are most of the other covariates. The remaining models therefore all make use of the System GMM estimator.

The baseline model 2 accounts for the endogeneity of the lagged dependent variable and the debt through the GMM-style instruments. The estimates thus obtained are consistent if the underlying assumptions hold. The pertinent test statistics are reported at the bottom of Table 1. While we expect first-order autocorrelation (AR (1), by construction), second-order autocorrelation AR (2) would question the validity of the GMM-style instruments. None of the models violates the requirements. Also, to successfully eliminate endogeneity, the instruments must be exogenous. The exogeneity of instruments is the null-hypothesis of the Hansen test, which accordingly should never be rejected. All our estimates satisfy this criterion too. Admittedly, the Hansen test weakens with a higher instrument count, which is why we strongly restrict the creation of internal instruments. Specifically, the depth of the GMM-instruments only ranges from the second to the third lag, resulting in a total of 41 instruments in the baseline regression; the sheer number of regressors is the main driver of the instrument count.

Focusing on the coefficients of the baseline model 2, the lagged dependent variable shows a highly significant value of 0.877 , which exceeds the downward biased OLS estimate of the model (1). The positive significant effect reflects the persistence of cantonal interest spreads that come about due to having long-term bonds with fixed yields in the cantonal portfolio. At the same time, the debt significantly determines the interest spread, with an expected positive sign. As concerns the control variables, two variables in the category budget stability provide some evidence for their significant effect on the interest spread. Both the interest receivable and the tax revenue affect the interest spread negatively, as expected. Apart from that, only nominal GDP, unemployment, and the accounting standard show a coefficient different from zero at the $10 \%$ significance level. $^{13}$

In this, counter to expectations, we were surprised to find a negative GDP coefficient and positive unemployment coefficient. To explain this, we would like to stress the meager impact the economic situation has. Increasing the GDP by one standard deviation widens the interest spread by $8 \%(=0.004 \times 19.903)$ as compared to a $27 \%$ $(=0.048 \times 5.621)$ augmentation when increasing the debt by one standard deviation. ${ }^{14}$ Given that small amplitude investors seem rather focus on direct effects of an economic boom, such as rising tax revenues.

To check the robustness of our main result, we altered several specifications. Model 3 accounts for potential identification problems when disregarding non-administrative assets and equity. As these two variables are only available starting in 1990, the number of observations drops considerably. The resulting debt coefficient rises marginally to 0.055 and remains significant. Model 4 assesses the coefficients' sensitivity to time-fixed effects and includes them, which drastically increases the instrument count to 105 . In reaction to that, the 
Table 1 Regression results

\begin{tabular}{|c|c|c|c|c|c|c|c|c|c|c|c|c|}
\hline & $\begin{array}{l}\text { (1) } \\
\text { Fixed } \\
\text { effects }\end{array}$ & $\begin{array}{l}\text { (2) } \\
\text { Baseline }\end{array}$ & $\begin{array}{l}\text { (3) Assets } \\
\text { and equity }\end{array}$ & $\begin{array}{l}\text { (4) Year } \\
\text { dummies }\end{array}$ & $\begin{array}{l}\text { (5) Two } \\
\text { step }\end{array}$ & $\begin{array}{l}\text { (6) } \\
\text { Endogenous }\end{array}$ & (7) Lags & $\begin{array}{l}\text { (8) No GE } \\
\text { and BS }\end{array}$ & $\begin{array}{l}\text { (9) Interest } \\
\text { rate }\end{array}$ & $\begin{array}{l}\text { (10) No } \\
\text { conditions }\end{array}$ & $\begin{array}{l}\text { (11) No } \\
\text { capacity }\end{array}$ & $\begin{array}{l}\text { (12) No } \\
\text { stability }\end{array}$ \\
\hline \multirow{2}{*}{$\begin{array}{l}\text { Lagged dependent } \\
\text { variable }\end{array}$} & $0.761^{* * *}$ & $0.877^{* * *}$ & $0.769^{* * *}$ & $0.592^{* * *}$ & $0.791^{* * *}$ & $0.646^{* * *}$ & $0.826^{* * *}$ & $0.854^{* * *}$ & $0.750^{* * *}$ & $0.894^{* * *}$ & $0.816^{* * *}$ & $0.828^{* * *}$ \\
\hline & $(0.057)$ & $(0.119)$ & $(0.128)$ & $(0.093)$ & $(0.179)$ & $(0.116)$ & $(0.107)$ & $(0.129)$ & $(0.074)$ & $(0.125)$ & $(0.130)$ & $(0.132)$ \\
\hline \multirow{2}{*}{$\begin{array}{l}\text { Debt (1000 CHF } \\
\text { per capita) }\end{array}$} & 0.004 & $0.048^{* *}$ & $0.055^{* *}$ & $0.039^{* *}$ & $0.126^{* *}$ & $0.034^{*}$ & $0.037^{* *}$ & $0.087^{* *}$ & $6.867^{* *}$ & $0.051^{* *}$ & $0.033^{*}$ & $0.030^{*}$ \\
\hline & $(0.007)$ & $(0.019)$ & $(0.023)$ & $(0.018)$ & $(0.053)$ & $(0.020)$ & $(0.017)$ & $(0.039)$ & $(2.992)$ & $(0.019)$ & $(0.017)$ & $(0.015)$ \\
\hline \multirow{2}{*}{$\begin{array}{l}\text { Cantonal overall } \\
\text { fiscal balance } \\
\text { ( } 1000 \text { CHF per } \\
\text { capita) }\end{array}$} & 0.043 & 0.060 & 0.021 & 0.031 & 0.158 & 0.093 & 0.058 & $0.087^{* *}$ & -0.775 & 0.066 & 0.059 & \\
\hline & $(0.035)$ & $(0.039)$ & $(0.044)$ & $(0.040)$ & $(0.101)$ & $(0.057)$ & $(0.038)$ & $(0.036)$ & (3.499) & $(0.039)$ & $(0.038)$ & \\
\hline \multirow{2}{*}{$\begin{array}{l}\text { Equity (in } 1000 \\
\text { CHF per capita) }\end{array}$} & & & $0.036^{* *}$ & & & & & & & & & \\
\hline & & & $(0.014)$ & & & & & & & & & \\
\hline \multirow{2}{*}{$\begin{array}{l}\text { Cantonal non- } \\
\text { administrative } \\
\text { assets (in } 1000 \\
\text { CHF per capita) }\end{array}$} & & & -0.027 & & & & & & & & & \\
\hline & & & $(0.018)$ & & & & & & & & & \\
\hline \multirow{2}{*}{$\begin{array}{l}\text { Interest receivable } \\
\text { (1000 CHF per } \\
\text { capita) }\end{array}$} & -0.110 & $-0.187^{* *}$ & $-0.190^{* *}$ & $-0.123^{*}$ & -0.462 & -0.211 & $\begin{array}{l}- \\
0.179^{* *}\end{array}$ & $-0.214^{* *}$ & -20.094 & $-0.193^{* *}$ & $\begin{array}{l}- \\
0.150^{* *}\end{array}$ & \\
\hline & $(0.089)$ & $(0.077)$ & $(0.071)$ & $(0.066)$ & $(0.624)$ & $(0.132)$ & $(0.071)$ & $(0.079)$ & (13.034) & $(0.078)$ & $(0.066)$ & \\
\hline \multirow{2}{*}{$\begin{array}{l}\text { Tax revenue (1000 } \\
\text { CHF per capita) }\end{array}$} & -0.025 & $-0.112^{* *}$ & -0.068 & $-0.091^{*}$ & $-0.264^{* *}$ & $-0.095^{*}$ & $-0.083^{*}$ & $-0.118^{* *}$ & $-15.553^{* *}$ & $-0.120^{* *}$ & $-0.060^{*}$ & \\
\hline & $(0.037)$ & $(0.045)$ & $(0.040)$ & $(0.047)$ & $(0.125)$ & $(0.052)$ & $(0.042)$ & $(0.043)$ & $(7.527)$ & $(0.046)$ & $(0.035)$ & \\
\hline \multirow{2}{*}{$\begin{array}{l}\text { Municipal fiscal } \\
\text { balance (1000 } \\
\text { CHF per capita) }\end{array}$} & -0.040 & 0.002 & 0.024 & $0.301^{* *}$ & -0.645 & 0.052 & 0.000 & -0.013 & 21.012 & -0.012 & -0.008 & \\
\hline & $(0.075)$ & $(0.083)$ & $(0.083)$ & $(0.109)$ & $(0.729)$ & $(0.103)$ & $(0.081)$ & $(0.081)$ & $(12.352)$ & $(0.079)$ & $(0.070)$ & \\
\hline \multirow{2}{*}{$\begin{array}{l}\text { No bailout } \\
\text { (dummy = } 1 \\
\text { after 2003) }\end{array}$} & $\begin{array}{l}- \\
0.105^{* *}\end{array}$ & 0.041 & 0.014 & 0.848 & $0.976^{*}$ & -0.073 & -0.005 & 0.040 & 9.018 & 0.044 & 0.007 & \\
\hline & $(0.041)$ & $(0.071)$ & $(0.067)$ & $(0.763)$ & $(0.560)$ & $(0.104)$ & $(0.063)$ & $(0.074)$ & $(10.832)$ & $(0.083)$ & $(0.070)$ & \\
\hline \multirow{2}{*}{$\begin{array}{l}\text { Municipal fiscal } \\
\text { balance X no } \\
\text { bailout }\end{array}$} & 0.169 & 0.048 & -0.012 & -0.197 & 0.399 & -0.043 & 0.061 & 0.012 & -24.251 & 0.097 & 0.036 & \\
\hline & $(0.147)$ & $(0.123)$ & $(0.126)$ & $(0.146)$ & $(0.628)$ & $(0.154)$ & $(0.125)$ & $(0.114)$ & (19.478) & $(0.124)$ & $(0.123)$ & \\
\hline \multirow{2}{*}{$\begin{array}{l}\text { Cantonal nominal } \\
\text { GDP ( } 1000 \mathrm{CHF} \\
\text { per capita) }\end{array}$} & 0.004 & $0.004^{*}$ & 0.002 & 0.001 & $0.004^{*}$ & 0.004 & 0.003 & 0.004 & -0.003 & 0.003 & & $-0.005^{*}$ \\
\hline & $(0.004)$ & $(0.002)$ & $(0.002)$ & $(0.002)$ & $(0.002)$ & $(0.002)$ & $(0.002)$ & $(0.003)$ & $(0.289)$ & $(0.002)$ & & $(0.002)$ \\
\hline \multirow[t]{2}{*}{ Log (population) } & -0.335 & -0.006 & $0.039^{*}$ & $0.046^{*}$ & $0.151^{*}$ & 0.026 & 0.003 & -0.017 & 1.740 & 0.001 & & 0.006 \\
\hline & $(0.412)$ & $(0.018)$ & $(0.022)$ & $(0.026)$ & $(0.088)$ & $(0.035)$ & $(0.016)$ & $(0.023)$ & (3.449) & $(0.018)$ & & $(0.028)$ \\
\hline \multirow{2}{*}{$\begin{array}{l}\text { Population growth } \\
\text { (in \%) }\end{array}$} & 0.008 & -0.011 & -0.005 & 0.019 & -0.005 & 0.012 & -0.010 & -0.004 & 2.000 & -0.014 & & -0.004 \\
\hline & $(0.021)$ & $(0.021)$ & $(0.024)$ & $(0.022)$ & $(0.039)$ & $(0.034)$ & $(0.021)$ & $(0.026)$ & $(4.701)$ & $(0.020)$ & & $(0.020)$ \\
\hline \multirow{2}{*}{$\begin{array}{l}\text { Elderly (as \% of } \\
\text { total population) }\end{array}$} & -0.007 & -0.003 & 0.009 & $0.022^{*}$ & 0.030 & 0.005 & -0.002 & -0.009 & 1.270 & -0.002 & & -0.014 \\
\hline & $(0.015)$ & $(0.006)$ & $(0.011)$ & $(0.013)$ & $(0.036)$ & $(0.013)$ & $(0.006)$ & $(0.013)$ & $(0.854)$ & $(0.006)$ & & $(0.014)$ \\
\hline \multirow{2}{*}{$\begin{array}{l}\text { Young (as } \% \text { of } \\
\text { total population) }\end{array}$} & -0.001 & -0.005 & 0.025 & 0.003 & 0.061 & -0.005 & -0.003 & -0.006 & -2.239 & -0.005 & & -0.003 \\
\hline & $(0.017)$ & $(0.007)$ & $(0.015)$ & $(0.015)$ & $(0.040)$ & $(0.013)$ & $(0.007)$ & $(0.010)$ & $(1.402)$ & $(0.008)$ & & $(0.008)$ \\
\hline \multirow[t]{2}{*}{$\begin{array}{l}\text { Unemployment } \\
\text { (in \%) }\end{array}$} & 0.001 & $-0.026^{*}$ & $-0.029^{* *}$ & -0.006 & $-0.061^{*}$ & -0.018 & -0.019 & $-0.033^{*}$ & -3.419 & $-0.023^{*}$ & & $-\overline{0.025^{* *}}$ \\
\hline & $(0.010)$ & $(0.013)$ & $(0.012)$ & $(0.027)$ & $(0.030)$ & $(0.021)$ & $(0.012)$ & $(0.017)$ & $(2.740)$ & $(0.012)$ & & $(0.012)$ \\
\hline \multirow{2}{*}{$\begin{array}{l}\text { Bourgeois parties } \\
\text { in executive (as \% } \\
\text { of all members) }\end{array}$} & 0.001 & 0.001 & 0.001 & -0.001 & 0.001 & 0.000 & 0.001 & 0.001 & -0.158 & 0.001 & & 0.001 \\
\hline & $(0.002)$ & $(0.001)$ & $(0.001)$ & $(0.001)$ & $(0.002)$ & $(0.002)$ & $(0.001)$ & $(0.001)$ & $(0.168)$ & $(0.001)$ & & $(0.001)$ \\
\hline \multirow{2}{*}{$\begin{array}{l}\text { Referendum } \\
\text { stringency (index) }\end{array}$} & -0.010 & -0.015 & 0.006 & 0.002 & 0.019 & -0.062 & -0.009 & -0.004 & -0.991 & & 0.003 & 0.004 \\
\hline & $(0.022)$ & $(0.013)$ & $(0.014)$ & $(0.017)$ & $(0.039)$ & $(0.069)$ & $(0.012)$ & $(0.015)$ & $(2.124)$ & & $(0.008)$ & $(0.011)$ \\
\hline \multirow{2}{*}{$\begin{array}{l}\text { Accounting } \\
\text { standard (index) }\end{array}$} & -0.081 & $-0.101^{*}$ & $-0.256^{* * *}$ & 0.007 & $-0.347^{* *}$ & -0.076 & $-0.099^{*}$ & $-0.117^{*}$ & 2.263 & & $-0.085^{*}$ & $-0.100^{*}$ \\
\hline & $(0.054)$ & $(0.050)$ & $(0.091)$ & $(0.043)$ & $(0.164)$ & $(0.075)$ & $(0.051)$ & $(0.068)$ & $(3.600)$ & & $(0.047)$ & $(0.055)$ \\
\hline \multirow{2}{*}{$\begin{array}{l}\text { Debt brake } \\
\text { (index) }\end{array}$} & 0.019 & 0.014 & 0.000 & -0.003 & -0.086 & -0.064 & 0.004 & 0.025 & 2.700 & & 0.002 & 0.021 \\
\hline & $(0.036)$ & $(0.015)$ & $(0.023)$ & $(0.024)$ & $(0.055)$ & $(0.072)$ & $(0.015)$ & $(0.021)$ & (2.863) & & $(0.011)$ & $(0.026)$ \\
\hline
\end{tabular}


Table 1 Regression results (Continued)

\begin{tabular}{|c|c|c|c|c|c|c|c|c|c|c|c|c|}
\hline & $\begin{array}{l}\text { (1) } \\
\text { Fixed } \\
\text { effects }\end{array}$ & $\begin{array}{l}(2) \\
\text { Baseline }\end{array}$ & $\begin{array}{l}\text { (3) Assets } \\
\text { and equity }\end{array}$ & $\begin{array}{l}\text { (4) Year } \\
\text { dummies }\end{array}$ & $\begin{array}{l}\text { (5) Two } \\
\text { step }\end{array}$ & $\begin{array}{l}\text { (6) } \\
\text { Endogenous }\end{array}$ & (7) Lags & $\begin{array}{l}\text { (8) No GE } \\
\text { and BS }\end{array}$ & $\begin{array}{l}\text { (9) Interest } \\
\text { rate }\end{array}$ & $\begin{array}{l}\text { (10) No } \\
\text { conditions }\end{array}$ & $\begin{array}{l}\text { (11) No } \\
\text { capacity }\end{array}$ & $\begin{array}{l}\text { (12) No } \\
\text { stability }\end{array}$ \\
\hline \multirow{2}{*}{$\begin{array}{l}\text { Election year } \\
\text { (dummy) }\end{array}$} & 0.035 & 0.041 & 0.049 & $0.034^{*}$ & 0.062 & $0.513^{* * *}$ & 0.041 & 0.044 & 3.256 & & 0.042 & 0.036 \\
\hline & $(0.027)$ & $(0.028)$ & $(0.036)$ & $(0.019)$ & $(0.039)$ & $(0.175)$ & $(0.027)$ & $(0.030)$ & (3.120) & & $(0.027)$ & $(0.027)$ \\
\hline \multirow{2}{*}{$\begin{array}{l}\text { Risk-free rate } \\
\text { (in basis points) }\end{array}$} & & & & & & & & & $0.226^{* * *}$ & & & \\
\hline & & & & & & & & & $(0.046)$ & & & \\
\hline$N$ & 841 & 841 & 618 & 841 & 841 & 841 & 841 & 773 & 884 & 841 & 841 & 841 \\
\hline $\begin{array}{l}\text { Number of } \\
\text { groups }\end{array}$ & 26 & 26 & 26 & 26 & 26 & 26 & 26 & 24 & 26 & 26 & 26 & 26 \\
\hline $\begin{array}{l}\text { Number of } \\
\text { instruments }\end{array}$ & & 41 & 45 & 105 & 41 & 47 & 47 & 41 & 41 & 33 & 29 & 29 \\
\hline $\begin{array}{l}\text { F statistic entire } \\
\text { model }\end{array}$ & 88.22 & $68.62^{* * *}$ & $71.82^{* *}$ & $53.68^{* * *}$ & $28.79^{* * *}$ & $73.39^{* * *}$ & $81.45^{* * *}$ & $100.60^{* * *}$ & $823.49 * * *$ & $62.25^{* * *}$ & $41.56^{* * *}$ & $46.70^{* * *}$ \\
\hline $\begin{array}{l}\text { Hansen statistic } \\
\text { (chi2) }\end{array}$ & & 8.54 & 9.27 & 0.00 & 8.54 & 7.80 & 10.44 & 8.04 & 8.97 & 12.17 & 15.08 & 16.18 \\
\hline$A R(1)$ & & $-2.74^{* * *}$ & $-2.37^{* *}$ & $-3.41^{* * *}$ & $-2.73^{* * *}$ & $-3.04^{* * *}$ & $-2.75^{* * *}$ & $-2.62^{* * *}$ & $-2.77^{* *}$ & $-2.68^{* * *}$ & $-2.48^{* *}$ & $-2.75^{* * *}$ \\
\hline$A R(2)$ & & 1.11 & 0.98 & 0.80 & 1.08 & -0.52 & 1.06 & 0.79 & 1.01 & 1.20 & 1.09 & 1.12 \\
\hline
\end{tabular}

Notes: System GMM estimation (one-step) with standard errors corrected for finite samples and clustered at cantonal level in parentheses. Significance levels: ${ }^{* *} 1 \%$; ${ }^{*} 5 \%$, and ${ }^{*} 10 \%$. The dependent variable is the subsequent $(t+1)$ cantonal log of the spread between the interest rate on the debt and the risk-free rate. Endogenous regressors: "lagged dependent variable" and debt per capita (except in model 4); instruments: tax revenue forecasting misestimations, GMM-style instruments of endogenous regressors (lags 2 to 3, collapsed)

coefficient of the debt drops to 0.039 , but it is still statistically significant. The lower coefficient results from overall positive time-fixed effects (not reported) that absorb symmetric cantonal changes of the debt and the interest spread. In contrast to the one-step estimation as it is applied in the baseline model, the two-step estimation holds the promise of yielding more efficient coefficient estimates while providing over-optimistic standard errors for finite samples. In response, Windmeijer (2005) developed a correction for small samples. However, the re-estimation of the baseline model using the two-step procedure (model 5) and the Windmeijer-correction produces larger standard errors. In consequence, we use the one-step estimator in the baseline model. It is noteworthy, nevertheless, that the debt coefficient resulting from the two-step estimator is considerably higher, indicating a possible underestimation in the baseline model. In model 6 , we acknowledge the idea that increasing the stringency of the debt brake is a response to past deficits (Feld and Kirchgässner, 2008). A similar argument could be made for the interest rate, which introduces some endogeneity into the model, reducing the credibility of the debt coefficient. The sixth model therefore declares the regressors of the institutional conditions category as endogenous and, in turn, constructs GMM-style instruments with them. This modification reduces the debt coefficient slightly to 0.034 . Model 7 increases the instrument count by deepening them to the fifth lag in order to evaluate their influence on the estimated coefficients. The resulting debt coefficient remains virtually unchanged in comparison to the baseline model.
While the previous model adjustments justify the specifications of the baseline model, two further estimations emphasize the robustness of the results from a different perspective. Model 8 acknowledges Basel City and Geneva as outliers and re-estimates the baseline model without the respective observations from these two cases. The resulting debt coefficient jumps to 0.087 , suggesting that the two cantons pull the average effect downwards in the baseline model. As a qualitative check on robustness, model 9 uses the plain interest rate instead of the logged interest spread as the dependent variable, leaving the full sample intact. This last model accounts for the problematic sample selection which is due to the definition of the risk-free rate. Even if the coefficient is not quantitatively comparable, the result supports a positive and significant effect of the debt on the interest rate.

The last three models 10 to 12 drop one category of controls each. In contrast to model 10, where the debt coefficient remains unchanged, dropping the respective variables leads to a decline of the debt coefficient in model 11 and 12, which represents an omitted variable bias.

Overall, model 2 appears to be a reasonable baseline for estimating the optimal debt level in the next subsection. The point estimate of 0.048 for the debt coefficient is situated in between the highest and lowest estimates of all the models. Since a higher coefficient translates into a steeper interest curve, the more conservative (lower) the resulting optimal debt level, the higher the estimated debt coefficient.

Figure 4 in the Appendix illustrates the predicted interest rate curves in 2014, a year in which capital markets 
performed well, for cantons selected to vary by size, language, and urbanization. Out of the 26 cantons, the 95\% confidence interval covers the true value (including all the cantons shown in Fig. 4 in the Appendix) in 18 cases; the model overestimates the interest rate for 2 cantons and underestimates it in 5 cases. There is no estimation for the canton of Zug, as it served as proxy for the risk-free rate in 2014. This finding underscores the precision of the baseline regression.

Although the abscissa covers different ranges of debt per capita, there are different shapes and levels of the interest rate curve. While Geneva is the most indebted (nearly 34,000 Swiss francs per capita), it still enjoys a lower interest rate than wealthier cantons (161 basis points). If all cantons had to manage a debt equivalent to Geneva's in 2014, their interest rate would vary between 44 basis points (Appenzell Inner-Rhodes) and 758 basis points (Aargau), with an average of 369 basis points. This variation emphasizes how differently cantons can profit from leveraged investments. With reference to the median performance of the Swiss pension funds, their investments yield a return of 731 basis points (see Figure 3 in Appendix).

\subsection{Estimated profits}

Based on the interest rate curves and the returns, profits and optimal debt levels can be calculated optimizing Eq. (8). Figure 2 depicts the respective results for the same selection of cantons as above. The dashed vertical line on the left shows the initial debt level (i.e., $B_{0}$ ), where the cantons take no profits, since, by assumption, cantons hold no unbound assets providing a return. ${ }^{15}$ Decreasing the debt level beyond $B_{0}$ is impossible by definition, since the cantons use the initial debt to fund their productive capital. With new re-invested liabilities, the cantons generate additional profit until they reach the optimal debt level $B_{1}^{*}$ indicated by the right dashed line. The shape of the interest rate curve translates into $B_{1}^{*}$, or inversely, the optimal debt level informs the steepness of the interest rate curve.

If one takes the two cantons of Basel City (BS) and Geneva (GE), then their two graphs in Fig. 2 reveal a similar $B_{1}^{*}$. Therefore, the underlying interest rate curves of the two cantons resemble each other (see Figure 4 in the Appendix). At the same time, Basel City has a higher profit potential since it starts at a lower initial debt level. Among the cantons portrayed in Fig. 2, Obwalden (OW) draws the highest profit, reaching 942 Swiss francs per capita (12.57\% of its total receipts). The required debt amounts to 13 times the initial debt level of 1962 Swiss francs per capita. By contrast, the canton of Geneva already operates nearly at its optimal debt level and has a potential return of only 717 Swiss francs per capita $(0.78 \%$ of its total receipts) when increasing its debt by $16 \%$.
While these examples give an impression of the profit potential in selected cantons in a specific year, they cannot provide the broader picture. For that purpose, Table 2 summarizes the results when exploiting the entire data set from 1997 (the first year when the performance of the Swiss pension fund was published) to 2015. For each equation parameter (5)-except the return rate, whose values are illustrated in Figure 3 in Appendix-, the table lists the summary statistics for three different debt strategies. In the first strategy, the cantons adjust their debt level each year to the optimum $B_{1}^{*}$. The resulting profit accordingly serves as a benchmark for the other strategies, since a canton cannot do better than that. The other two strategies account for the reasonable doubt that the optimum might not be feasible (and a too exorbitant debt level may potentially trigger political protest). Therefore, the second strategy limits the adjusted debt level to $100 \%$ of the receipts, following the recommendation of the Conference of Cantonal Finance Ministers (2008). Still, the capital markets might not accept a sudden and vigorous adjustment of the debt level. Accordingly, the third strategy only allows an adjustment of the debt level to the mean value of the last year and the current optimum (i.e., a moving average of 2 years).

Focusing on the first strategy, the statistics of the initial debt level $B_{0}$ provide information about a subsample of the data in Table 3. When only considering the period from 1997 to 2015, the mean debt per capita rises to 7027 Swiss francs per capita (in comparison to 6083 Swiss francs for the entire sample). If the cantons had adjusted the debt each year to their individual optimum $\left(\hat{B}^{*}\right)$, they would have more than doubled the initial debt to 17,736 Swiss francs per capita on average. In terms of the annual receipts, the adjusted debt is almost double. In one extreme case, a canton would need to adjust the debt to almost seven times its receipts in 1 year. This raises some doubt whether a canton can really issue that volume of bonds in a single year. Consequently, we consider some more conservative strategies below.

The combination of the two lines in Table 2 listing the estimated $\left(\hat{i}_{0}\right)$ and the observed initial interest rate $\left(i_{0}\right)$ is an indicator of the model's goodness of fit. The resemblance of their mean and median underpins the adequacy of the estimations. At the optimal debt level, the interest rate $\hat{i}_{1}$ would lie not even one percentage point higher at $3.28 \%$ on average. The minimum value of $0.35 \%$ stems from setting the optimal debt level equal to the initial debt level. This constellation appears several times, and it typically occurs in years with a low return rate. Feeding the model with all previously discussed parameters yields a profit from the leveraged investments 

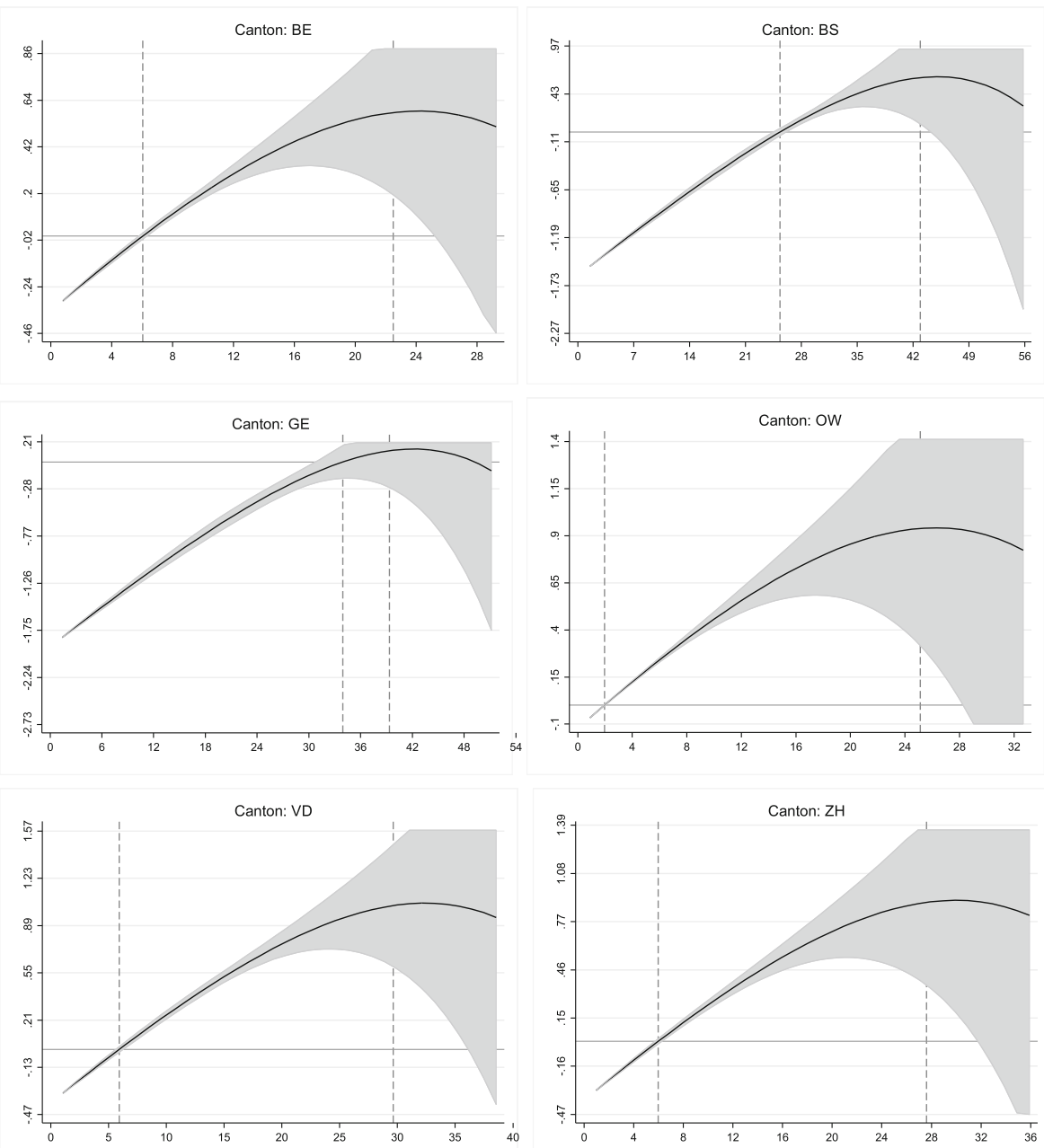

Vertical axis: profit (in 1'000 Swiss francs per capita); horizontal axis: debt (in 1'000 Swiss francs per capita)

$\begin{array}{ll}- & \text { profit curve } \\ ---= & \text { initial debt level }\left(B_{0}\right)\left[\text { left]; optimal debt level }\left(B_{1}^{*}\right) \text { [right] }\right.\end{array}$

Fig. 2 Predicted profit curve from leveraged investments in 2014

which would cover $4.78 \%$ of total cantonal receipts. Considering the much lower median value of $1.45 \%$ shows how strongly right-skewed the distribution is. That is, the average is driven by few high values (up to $50.25 \%$ ), though these extreme values drop dramatically when truncating the maximum debt. Politically, it seems easier to record and report several years with rather low but positive profits and a few quite negative ones rather than the revers. The last line of the upper part in Table 2 therefore gives an idea of the distribution of the profitable years per canton. Out of the 19 years, nearly 12 turn out to be profitable on average. Yet, one canton would have never benefitted.

Strategy 2 limits the annual debt increase to $100 \%$ of the receipts. Most cantons actually hit the boundary as the median of the $\hat{\mathrm{B}}_{1}$-to-rev. ratio of $100 \%$ shows. Still, there are cantons with debt levels above the truncation because their initial debt level exceeded the limit. Consequently, no adjustment took place in these cantons. The truncation brings down the adjusted debt level to 9367 Swiss francs per capita, which corresponds to almost halving the debt in comparison to the first strategy. Of course, limiting the debt increase impacts the profit, whose mean sharply decreases to $1.11 \%$ of total receipts. Nevertheless, one canton reached a value of $6.98 \%$. Banning high debt values also cuts the interest rates, whose mean shrinks to $2.54 \%$ compared to $3.28 \%$ in strategy 1 .

Finally, strategy 3 leaves the truncation point at $100 \%$ of the receipts and it then adjusts the debt to the mean between the previous and the current year's optimum. 
Table 2 Descriptive statistics of profit sensitivity

\begin{tabular}{|c|c|c|c|c|c|}
\hline Debt strategy/parameter & Median & Mean & Std. dev. & Min. & Max. \\
\hline \multicolumn{6}{|l|}{ (1) annual adjustment to optimal debt level } \\
\hline$B_{0}$ (initial debt level) & 5.18 & 7.03 & 6.55 & 1.05 & 36.07 \\
\hline$\hat{\mathrm{B}}^{*}$ (optimal debt level) & 16.75 & 17.74 & 12.08 & 1.80 & 66.55 \\
\hline$\hat{B}_{1}^{*} /$ rev. (optimal debt in \% of receipts) & $161.41 \%$ & $178.67 \%$ & 1.34 & $0.00 \%$ & $720.07 \%$ \\
\hline$i_{0}$ (observed initial interest rate) & $2.46 \%$ & $2.51 \%$ & 0.01 & $0.00 \%$ & $6.44 \%$ \\
\hline$\hat{\mathrm{i}}_{0}$ (estimated initial interest rate based on $B_{0}$ ) & $2.46 \%$ & $2.41 \%$ & 0.01 & $0.09 \%$ & $5.28 \%$ \\
\hline$\hat{\mathrm{i}}_{1}$ (estimated interest rate at $\hat{B}^{*}$ ) & $3.24 \%$ & $3.28 \%$ & 0.01 & $0.35 \%$ & $6.88 \%$ \\
\hline$\hat{\pi}$ (estimated profit [in \% of total receipts]) & $1.45 \%$ & $4.78 \%$ & 7.05 & $0.00 \%$ & $50.25 \%$ \\
\hline Profitable years per canton & 14.50 & 11.54 & 7.21 & 0 & 19 \\
\hline \multicolumn{6}{|l|}{ (2) Annual adjustment up to $100 \%$ of receipts } \\
\hline$B_{0}$ (initial debt level) & 5.18 & 7.03 & 6.55 & 1.05 & 36.07 \\
\hline$\hat{\mathrm{B}}_{1}$ (adjusted debt level) & 8.17 & 9.37 & 6.18 & 1.80 & 36.07 \\
\hline$\hat{\mathrm{B}}_{1} /$ rev (adjusted debt in \% of receipts) & $100.00 \%$ & $87.28 \%$ & 0.37 & $0.00 \%$ & $211.41 \%$ \\
\hline$i_{0}$ (observed initial interest rate) & $2.46 \%$ & $2.51 \%$ & 0.01 & $0.00 \%$ & $6.44 \%$ \\
\hline$\hat{\mathrm{i}}_{0}$ (estimated initial interest rate based on $B_{0}$ ) & $2.46 \%$ & $2.41 \%$ & 0.01 & $0.09 \%$ & $5.28 \%$ \\
\hline$\hat{\mathrm{i}}_{1}$ (estimated interest rate at $\hat{B}^{*}$ ) & $2.60 \%$ & $2.54 \%$ & 0.01 & $0.13 \%$ & $5.96 \%$ \\
\hline$\hat{\pi}$ (estimated profit [in \% of total receipts]) & $0.13 \%$ & $1.11 \%$ & 1.55 & $0.00 \%$ & $6.98 \%$ \\
\hline Profitable years per canton & 11.50 & 9.69 & 6.22 & 0 & 18 \\
\hline \multicolumn{6}{|c|}{ (3) 2 years moving average adjustment up to $100 \%$ of receipts } \\
\hline$B_{0}$ (initial debt level) & 5.16 & 7.02 & 6.60 & 1.05 & 36.07 \\
\hline$\hat{\mathrm{B}}_{1}$ (adjusted debt level) & 7.94 & 9.39 & 6.04 & 1.93 & 35.54 \\
\hline$\hat{\mathrm{B}}_{1} /$ rev (adjusted debt in \% of receipts) & $94.63 \%$ & $86.26 \%$ & 0.33 & $0.00 \%$ & $204.77 \%$ \\
\hline$i_{0}$ (observed initial interest rate) & $2.40 \%$ & $2.42 \%$ & 0.01 & $0.00 \%$ & $5.86 \%$ \\
\hline$\hat{\mathrm{i}}_{0}$ (estimated initial interest rate based on $B_{0}$ ) & $2.39 \%$ & $2.33 \%$ & 0.01 & $0.09 \%$ & $5.28 \%$ \\
\hline$\hat{\mathrm{i}}_{1}$ (estimated interest rate at $\hat{\mathrm{B}}^{*}$ ) & $2.52 \%$ & $2.46 \%$ & 0.01 & $0.13 \%$ & $5.99 \%$ \\
\hline$\hat{\pi}$ (estimated profit [in \% of total receipts]) & $0.23 \%$ & $0.77 \%$ & 1.37 & $-6.61 \%$ & $6.06 \%$ \\
\hline Profitable years per canton & 12.00 & 11.15 & 5.15 & 1 & 18 \\
\hline
\end{tabular}

Notes: Unbalanced panel of 26 cantons and 19 years (1997 to 2015); $n=468$

Such calibration allows maladjustments and thereby also produces negative profits. At the bottom of the distribution, one canton must tolerate a painful loss of $-6.61 \%$ of its annual receipts. Nonetheless, the maximum value tenaciously sticks at plus $6 \%$, while on average, the cantons only benefit from a profit of $0.77 \%$. Interestingly, the number of profitable years lies above that of strategy 2 . The reason is that strategy 2 produces debt adjustments above the truncation point if the previous year's optimal debt is high enough. In sum, even with this rather conservative strategy, every canton except Geneva would have realized a positive profit over the entire time span from 1997 to 2015. Moreover, some cantons have considerable potential, particularly in later years. Obwalden, for instance, would have reached profits of 3.02\% (2012), $4.34 \%$ (2013), and $4.46 \%$ (2014).

\section{Conclusion}

This article connects the interest rate curve to the return attainable in the capital markets by tracing the borrowing cost of a state as a function of the debt level. The purpose was to assess the profit a state or canton can achieve by issuing loans and investing the raised capital afterwards in the capital markets. By imposing an increasing convex interest rate curve, our theory proposed that there was an optimal debt level. To estimate the coefficients of the variables determining the interest rate, panel data from the Swiss cantons from 1980 to 2015 served as our database. Taking the dynamics and endogeneity issues into account, a GMM estimation is the most appropriate method for the model. We approximated the return from the capital markets using median values of the performance of Swiss pension funds. 
Table 3 Descriptive statistics

\begin{tabular}{|c|c|c|c|c|c|}
\hline Variable & Source & Mean & $\begin{array}{l}\text { Std. } \\
\text { dev. }\end{array}$ & Min. & Max. \\
\hline Interest rate (in basis points) & $\begin{array}{l}\text { Own calculations based on data of the Swiss federal } \\
\text { finance administration }\end{array}$ & 336.043 & 122.71 & 8.297 & 783.488 \\
\hline $\begin{array}{l}\text { Risk-free rate [lowest cantonal interest rate per } \\
\text { annum] (in basis points) }\end{array}$ & $\begin{array}{l}\text { Own calculations based on data of the Swiss federal } \\
\text { finance administration }\end{array}$ & 149.071 & 70.467 & 0.371 & 238.63 \\
\hline Interest spread (in basis points) & $\begin{array}{l}\text { Own calculations based on data of the Swiss federal } \\
\text { finance administration }\end{array}$ & 186.972 & 84.343 & 1.453 & 581.618 \\
\hline Debt (in 1000 CHF per capita) & Swiss federal statistical office & 6.083 & 5.621 & 0.405 & 36.066 \\
\hline Cantonal overall fiscal balance (1000 CHF per capita) & Swiss federal finance administration & -0.076 & 0.538 & - & 2.692 \\
\hline Cantonal equity (1000 CHF per capita) ${ }^{a}$ & Swiss federal finance administration & 0.838 & 3.501 & $\begin{array}{l}- \\
17.025\end{array}$ & 20.584 \\
\hline $\begin{array}{l}\text { Cantonal non-administrative assets ( } 1000 \text { CHF per } \\
\text { capita) }^{a}\end{array}$ & Swiss federal finance administration & 4.421 & 3.187 & 0.722 & 21.295 \\
\hline Interest receivable (1000 CHF per capita) & Swiss federal finance administration & 0.278 & 0.239 & 0.038 & 1.759 \\
\hline Tax revenue (in 1000 CHF per capita) & Swiss federal finance administration & 3.467 & 2.271 & 0.718 & 14.486 \\
\hline Municipal overall fiscal balance (1000 CHF per capita) & Swiss federal finance administration & -0.018 & 0.221 & $-\overline{0}-814$ & 0.943 \\
\hline Nominal GDP (in 1000 CHF per capita) & BAK Basel Economics & 51.005 & 19.903 & 17.235 & 162.389 \\
\hline Log (population) & Swiss federal statistical office & 12.023 & 1.125 & 9.456 & 14.185 \\
\hline Population growth (in \%) & Swiss federal statistical office & 0.754 & 0.736 & $-\overline{1}-\mathbf{5 6 9}$ & 6.960 \\
\hline Elderly (as \% of total population) & Swiss federal statistical office & 15.141 & 2.196 & 10.183 & 21.756 \\
\hline Young (as \% of total population) & Swiss federal statistical office & 23.948 & 3.415 & 16.102 & 33.584 \\
\hline Unemployment (in \%) & Swiss federal statistical office & 2.252 & 1.725 & 0.000 & 7.800 \\
\hline Bourgeois parties in executive (as \% of all members) & Swiss federal statistical office & 43.518 & 20.394 & 0.000 & 100.000 \\
\hline Referendum stringency (index; 1 [hard] to 6 [easy]) & Frey and Stutzer (2000) & 3.856 & 1.296 & 0.000 & 6.000 \\
\hline Accounting standard (index; 1 [poor] to 3 [strong]) & Own inquiry & 1.090 & 0.354 & 1.000 & 3.000 \\
\hline Debt brake (index; 1 [poor] to 3 [restrictive]) & Feld and Kirchgässner (2008) & 0.572 & 0.978 & 0.000 & 3.000 \\
\hline No bailout (dummy = 1 after 2003) & & 0.321 & 0.467 & 0.000 & 1.000 \\
\hline
\end{tabular}

$n=841$ (unbalanced panel with $t=34$ and $N=26$ )

${ }^{a} n=618$

When optimizing the debt level each year, the cantons have the potential to generate $4.78 \%$ of their total receipts, on average, through leveraged investments. Yet, the optimal debt level strongly depends on the returns in the capital markets, which in turn fluctuates considerably from 1 year to the next. This creates doubt whether the cantons can annually adjust their debt level to the same extent. When limiting their yearly adjustments to $100 \%$ of their receipts, the profit drops to $1.11 \%$ on average.

The calculated profits are rather conservative, because the theoretical model abstracts from the fact that cantons already possess financial assets that yield a return. The model assumes that the cantons carry only administrative assets in their balance sheet, without financial gain. Having said this, the model accounts for risks only to a certain extent. Prediction errors of the return rate can lead to fatal debt adjustments that engender high losses. The third investment strategy gives an impression of losses when the canton cannot adjust its debt level immediately. Occasionally, the deficit climbs up to $6.61 \%$ of the total cantonal receipts. Risk-averse governments that reflect voter preferences would borrow less than the optimal debt level, which further cuts the profit potential.

One can use the hypothetical invested sum of all cantons in 2015 to show their importance in the capital market. Assuming the third strategy, together they would have invested 26.6 billion Swiss francs, while the market capitalization of the 20 shares of the Swiss Market Index amounts to 1128.3 billion Swiss francs in the same year. ${ }^{16}$ This comparison also supports our claim that the practice of cantonal leveraged investments probably would not have an effect on the return rates of the (international) capital markets. 
The governments must carefully plan any specific implementations of such practices. If the cantons enter the capital markets as significant investors, there is a high risk of politicization, rent-seeking, or even corruption (Bohn, 2002). So far, Basel City is the only canton which has installed a (partly politically independent) committee for asset and liability management (ALM). While this example of good governance, together with foreign experiences with public investment funds, could serve as a point of reference (Mitchell, Piggott, and Kumru, 2008), further research is needed with respect to the optimal checks and balances such investments would need.

A politician, or more concretely the finance minister, certainly has to bear in mind several aspects when considering debt as a revenue source. Even if she was risk-indifferent, as we assumed, voters penalize losses more sharply than they value gains. Moreover, the voters settle up with the politician relatively frequently each election year, which imposes inefficient incentives on the politician. Shortly before the election, he might reduce cantonal exposure to the capital market and reduce the gross debt in order to prevent any negative surprises, even if current returns would suggest investing more. Just after the election, he might invest too aggressively hoping that the voter will forget potential losses until the next election. Such issues could be addressed by limiting the political influence on the ALM committee and by separating the funds from cantonal accounting bodies and practices.

\section{Endnotes}

${ }^{1}$ The term "spread" denotes the difference between two rates. This might either be the difference between the risk-free rate and the interest rate on public debt (the interest spread), or the difference between the interest rate on public debt and the return rate of capital markets (the return spread).

${ }^{2}$ Usually, states already hold some liquid assets that are unbound; this is to guarantee, at any time, an immediate payment of current liabilities.

${ }^{3}$ Such an immediate raising of the interest rate for all outstanding debts abstracts from different maturity dates.

${ }^{4}$ At the same time, we assume that the return rate from the capital market $(r)$ and the economic growth $(g)$ are independent of the debt level. The latter relation has been discussed intensively in the literature (Herndon, Ash, and Pollin, 2014).

${ }^{5} \mathrm{~A}$ high persistence in the overall cantonal interest rate on the debt results from long-term cantonal bonds. They constitute the majority of the debt.
${ }^{6}$ Note the first differences $\Delta \epsilon_{c, t}=\epsilon_{c, t}-\epsilon_{c, t-1}$ and $\Delta \ln \left(s_{c, t}\right)=\ln \left(s_{c, t}\right)-\ln \left(s_{c, t-1}\right)$ where $\ln \left(s_{c, t}\right)=\delta \ln \left(s_{c,}\right.$ $t-1)+\gamma B_{c, t-1}+\boldsymbol{\beta} \boldsymbol{x}_{c, t-1}+\epsilon_{c, t-1}$. Hence, both differences share the term $\epsilon_{c, t-1}$ which explains why $E\left[\Delta \ln \left(s_{c, t}\right) \Delta \epsilon_{c, t}\right] \neq 0$.

${ }^{7}$ Their utility as instruments is only given though if $E\left[\Delta \ln \left(s_{c, t-1}\right) \Delta \epsilon_{c, t}\right]=0$, which can be tested (i.e., the autoregression AR (2) test in Table 1).

${ }^{8}$ Roodman's (2006) Stata command facilitates the practical application.

${ }^{9}$ We cannot exclude that the fiscal balance partly captures the effect of the debt on the interest rate since today's deficit contributes to tomorrow's debt. The debt coefficient would in this case be downward biased. Yet, the gross debt can vary independently from the fiscal balance (in our sample, the correlation amounts to - 0.18) as consists of more than the cumulated deficits.

${ }^{10} \mathrm{~A}$ parallel opposite effect on the expenditures is hardly observable in Switzerland since the cantons are not responsible for unemployment benefits.

${ }^{11}$ The correlation between the two alternative measures of the risk-free rate is 0.84 .

${ }^{12}$ For the US government, Bohn (2002) finds the social security trust fund to be the most appropriate to manage uncommitted public funds, when taking potential rentseeking into account.

${ }^{13}$ The effect of the accounting standard index follows expectations. Recoding the variable into dummies for the second generation of the harmonized accounting model (HAM2) and the international public sector accounting standards (IPSAS) reveals that it is the former accounting standard which mainly drives the coefficient. The latter dummy is not significant.

${ }^{14}$ Note that the coefficients indicate an interest spread adjustment in percent because the dependent variable is expressed in logarithmic terms. This is not equal to an adjustment in percentage points, which would admittedly be easier to interpret.

${ }^{15}$ This assumption diminishes the estimated profits and hence makes them more conservative, because current returns on unbound assets are not added to the profit. In practice, non-administrative (unbound) assets average $49.81 \%$ from 1990 to 2015, with a return of $1.37 \%$ of total receipts. Hence, they are taken into account when estimating the debt coefficient (by controlling for the interest receivable) holding a significant negative coefficient. Since the interest receivable and the debt are strongly positively correlated (0.85) omitting the former from the estimation equation would result in a lower (less conservative) estimate of the debt coefficient.

${ }^{16}$ Information retrieved from the annual statistics of SIX Swiss Exchange Ltd. (www.six-swiss-exchange.com/ statistics/annual_statistics/) 


\section{Appendix}

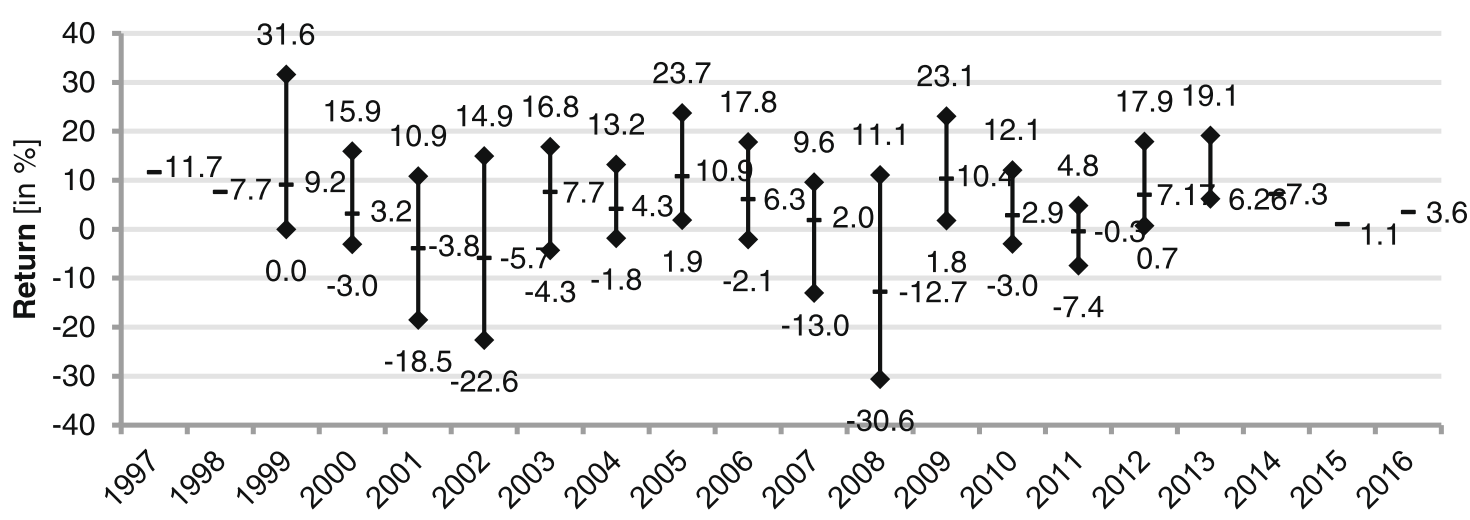

Fig. 3 Mean, minimal and maximal return of Swiss pension funds
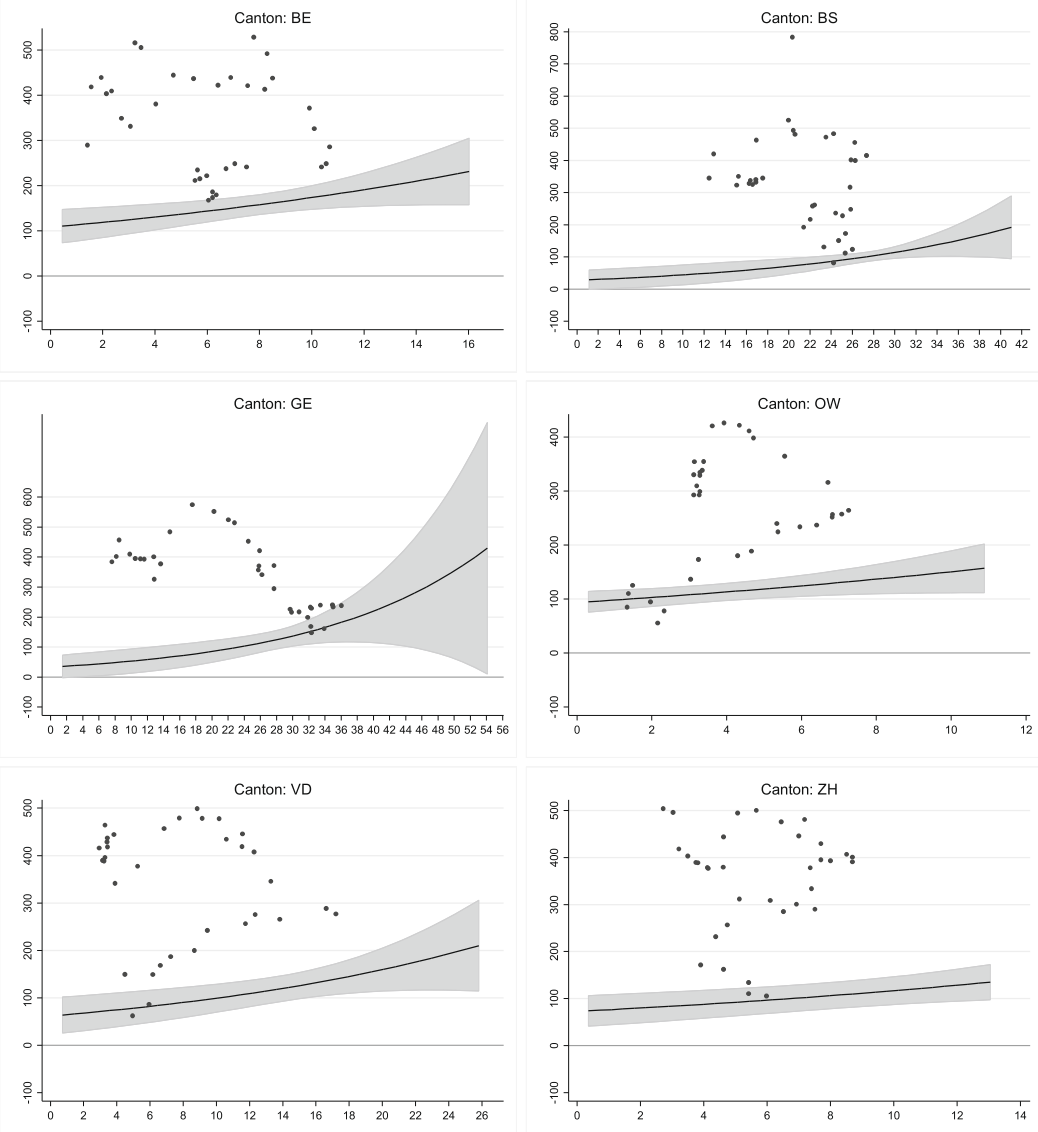

- interest rate curve

$95 \%$ confidence interval

- real observations per year

Notes: Vertical axis: interest rate (in basis points); horizontal axis: debt per capita (in 1'000 Swiss francs); interest rates conditional on the debt per capita - as predicted by the baseline model (1) with parameter values of the indicated cantons in 2014

Fig. 4 Predicted interest rate curve for the year 2014 


\section{Abbreviations}

AR: Autoregression; BE: Bern (canton); BS: Basel City (canton); CHF: Swiss francs; GDP: Gross domestic product; GE: Geneva (canton); GMM: General methods of moments; HAM2: Second generation of the harmonized accounting model; IPSAS: International public sector accounting standard; OW: Obwalden; VD: Vaud; ZH: Zurich (canton)

\section{Acknowledgements}

We thank Reiner Eichenberger (University of Fribourg, $\mathrm{CH}$ ) and Guido Modugno (MIB School of Management, Italy), the editors and two anonymous reviewers for their critical contributions during the development of the paper. Furthermore we are indebted to Michelle Bailat-Jones and John Bendix for their editing assistance.

\section{Funding}

This work was supported by the Institut de Hautes Études en Administration Publique (IDHEAP), University of Lausanne.

\section{Availability of data and materials}

The data sources are indicated in the descriptive statistics table. At this stage, we cannot share the entire database, as it will be used in future research.

\section{Authors' contributions}

Both authors read and approved the final manuscript.

\section{Authors' information}

Professor Nils Soguel holds the chair of public finance at the Swiss Graduate School of Public Administration (IDHEAP) where Ramon Christen wrote his dissertation.

\section{Competing interests}

The authors declare that they have no competing interests.

\section{Publisher's Note}

Springer Nature remains neutral with regard to jurisdictional claims in published maps and institutional affiliations.

\section{Author details}

${ }^{1}$ PricewaterhouseCoopers AG, Bahnhofplatz 10, 3001 Bern, Switzerland. ${ }^{2}$ University of Lausanne, IDHEAP, Rue de la Mouline 28, 1015 Lausanne, Switzerland.

Received: 14 March 2018 Accepted: 27 February 2019

Published online: 25 March 2019

\section{References}

Akitoby, B., \& Stratmann, T. (2008). Fiscal policy and financial markets. The Economic Journal, 118(533), 1971-1985 https://doi.org/10.1111/j.1468-0297. 2008.02198.x.

Arellano, M., \& Bond, S. (1991). Some tests of specification for panel data: Monte Carlo evidence and an application to employment equations. The Review of Economic Studies, 58(2), 277 https://doi.org/10.2307/2297968.

Attinasi, M., Checherita, C., \& Nickel, C. (2011). What explains the surge in euro area sovereign spreads during the financial crisis of 2007-2009? In Sovereign Debt, 1131 (pp. 407-414) https://doi.org/10.1002/9781118267073.ch46.

Barth, J. R., Iden, G., \& Russek, F. S. (1984). Do federal deficits really matter? Contemporary Economic Policy, 3(1), 79-95 https://doi.org/10.1111/j.14657287.1984.tb00788.x.

Bayoumi, T., Goldstein, M., \& Woglom, G. (1995). Do credit markets discipline sovereign borrowers? Evidence from U.S. states. Journal of Money, Credit and Banking, 27(4), 1046 https://doi.org/10.2307/2077788.

Blanchard, O. J., Chouraqui, J.-C., Hagemann, R., \& Sartor, N. (1991). The sustainability of fiscal policy: New answers to an old question. NBER Working Paper, R1547 Retrieved from https://ssrn.com/abstract=227461.

Blankart, C. B. (2017). Öffentliche Finanzen in der Demokratie. Munich: Verlag Franz Vahlen GmbH https://doi.org/10.15358/9783800653485.

Blundell, R., \& Bond, S. (1998). Initial conditions and moment restrictions in dynamic panel data models. Journal of Econometrics, 87(1), 115-143 https:// doi.org/10.1016/S0304-4076(98)00009-8.
Bohn, H. (1999). Fiscal policy and the Mehra-Prescott puzzle: On the welfare implications of budget deficits when real interest rates are low. Journal of Money, Credit and Banking, 31(1), 1 https://doi.org/10.2307/2601136.

Bohn, H. (2002). Government asset and liability management in an era of vanishing public debt. Journal of Money, Credit, and Banking, 34(3), 887-933 https://doi.org/10.1353/mcb.2002.0009.

Bohn, H. (2011). The economic consequences of rising U.S. government debt: Privileges at risk. FinanzArchiv: Public Finance Analysis, 67(3), 282-302 https:// doi.org/10.1628/001522111X600605.

Booth, L., Georgopoulos, G., \& Hejazi, W. (2007). What drives provincial-Canada yield spreads? Canadian Journal of Economics, 40(3), 1008-1032 https://doi. org/10.1111/j.1365-2966.2007.00440.x.

Capeci, J. (1994). Local fiscal policies, default risk, and municipal borrowing costs. Journal of Public Economics, 53(1), 73-89 https://doi.org/10.1016/00472727(94)90014-0.

Conference of Cantonal Finance Ministers. (2008). Harmonized accounting model for the Swiss cantons and municipalities. Bern: Conference of cantonal finance ministers Retrieved from http://www.srs-cspcp.ch/fr/manuel-mch2-versionintegrale-n18360.

Daldoss, M., \& Foraita, O. (2003). Bonitätsbeurteilung subnationaler Gebietskörperschaften in föderalistischen Staatsstrukturen. St. Gallen: Universität St. Gallen.

Das, U. S., Lu, Y., Papaioannou, M. G., \& Petrova, I. (2013). Sovereign risk and asset and liability management-Conceptual issues. Journal of Reviews on Global Economics, 2 https://doi.org/10.6000/1929-7092.2013.02.24.

De Mello, L. R. (2001). Fiscal decentralization and borrowing costs: The case of local governments. Public Finance Review, 29(2), 108-138 https://doi.org/10. 1177/109114210102900202.

Engen, E., \& Hubbard, R. G. (2004). Federal Government Debt and interest rates. NBER macroeconomics annual (Vol. 19). Cambridge: MIT Press Retrieved from https://www.nber.org/papers/w10681.

Feld, L. P., Kalb, A., Moessinger, M.-D., \& Osterloh, S. (2017). Sovereign bond market reactions to no-bailout clauses and fiscal rules - The Swiss experience. Journal of International Money and Finance, 70, 319-343 https:// doi.org/10.1016/j.jimonfin.2016.09.002.

Feld, L. P., \& Kirchgässner, G. (2008). On the effectiveness of debt brakes: The Swiss experience. In R. Neck \& J.-E. Sturm (Eds.), Sustainability of public debt (pp. 223-255). Cambridge: The MIT Press https://doi.org/10.7551/mitpress/ 9780262140980.003.0009

Frey, B. S., \& Stutzer, A. (2000). Happiness, economy and institutions. The Economic Journal, 110(466), 918-938 https://doi.org/10.1111/1468-0297.00570.

Giammarioli, N., Nickel, C., Rother, P., \& Vidal, J.-P. (2006). Assessing fiscal soundness: Theory and practice. SSRN Electronic Journal, 56. https://doi.org/ 10.2139/ssrn.2005166.

Greene, W. H. (2003). Econometric analysis. Essex: Pearson Education Limited.

Herndon, T., Ash, M., \& Pollin, R. (2014). Does high public debt consistently stifle economic growth? A critique of Reinhart and Rogoff. Cambridge Journal of Economics, 38(2), 257-279 https://doi.org/10.1093/cje/bet075.

Krishnakumar, J., Martin, M.-J., \& Soguel, N. (2010). Explaining fiscal balances with a simultaneous equation model of revenue and expenditure: A case study of Swiss cantons using panel data. Public Budgeting \& Finance, 30(2), 69-94 https://doi.org/10.1111/j.1540-5850.2010.00957.x.

Kumar, M. S., \& Baldacci, E. (2010). Fiscal deficits, public debt, and sovereign Bond yields. IMF Working Papers, 10(184), 1 https://doi.org/10.5089/ 9781455202188.001.

Küttel, D., \& Kugler, P. (2002). Explaining yield spreads of Swiss canton bonds: An empirical investigation. Financial Markets and Portfolio Management, 16(2), 208-218 https://doi.org/10.1007/s11408-002-0204-9.

Luechinger, S., \& Schaltegger, C. A. (2013). Fiscal rules, budget deficits and budget projections. International Tax and Public Finance, 20(5), 785-807 https://doi.org/10.1007/s10797-012-9245-9.

Manganelli, S., \& Wolswijk, G. (2009). What drives spreads in the euro area government bond market? Economic Policy, 24(58), 191-240 https://doi.org/ 10.1111/j.1468-0327.2009.00220.x.

Mehra, R., \& Prescott, E. C. (1985). The equity premium: A puzzle. Journal of Monetary Economics, 15(2), 145-161 https://doi.org/10.1016/0304-3932(85)90061-3.

Mitchell, O. S., Piggott, J., \& Kumru, C. (2008). Managing public investment funds: Best practices and new questions. Journal of Pension Economics and Finance, 7(03), 321 https://doi.org/10.1017/\$1474747208003818.

Nickell, S. (1981). Biases in dynamic models with fixed effects. Econometrica: Journal of the Econometric Society, 1417-1426. 
Poterba, J., \& Rueben, K. (1997). State Fiscal Institutions and the U.S. Municipal Bond Market. In J. M. Poterba \& J. von Hagen (Eds.), Fiscal Institutions and Fiscal Performance. Cambridge: University of Chicago Press Retrieved from https://www.nber.org/papers/w6237.

Roodman, D. (2006). How to do Xtabond2: An introduction to difference and system GMM in Stata. SSRN Electronic Journal, 9(1), 86-136 https://doi.org/10. 2139/ssrn.982943.

Schuknecht, L., von Hagen, J., \& Wolswijk, G. (2009). Government risk premiums in the bond market: EMU and Canada. European Journal of Political Economy, 25(3), 371-384 https://doi.org/10.1016/j.jpoleco.2009.02.004.

Swisscanto Vorsorge, A. G. (2017). Schweizer Pensionskassenstudie 2017. Zurich: Retrieved from hhttps://www.swisscanto.com/ch/de/is/vorsorgen/ pensionskassenstudie.html.

Windmeijer, F. (2005). A finite sample correction for the variance of linear efficient two-step GMM estimators. Journal of Econometrics, 126(1), 25-51 https://doi.org/10.1016/j.jeconom.2004.02.005.

\section{Submit your manuscript to a SpringerOpen ${ }^{\circ}$ journal and benefit from:}

- Convenient online submission

- Rigorous peer review

- Open access: articles freely available online

High visibility within the field

- Retaining the copyright to your article

Submit your next manuscript at $\boldsymbol{\nabla}$ springeropen.com 